\title{
Identification of benefits for the inhabits of Somesul Rece Natura 2000 Site
}

\author{
Ecaterina PAULIUC, , Marian PROOROCU, Ioan OROIAN, Antonia ODAGIU \\ ${ }^{1}$ University of Agricultural Science and Veterinary Medicine Cluj - Napoca, Manastur Street, \\ No. 3 - 5,400372 Cluj-Napoca, Romania'Tel.: +40264596384; Fax: +40 264593792 \\ *Corresponding author: sinzianapauliuc@yahoo.com \\ Bulletin USAMV series Agriculture 72(2)/2015 \\ Print ISSN 1843-5246; Electronic ISSN 1843-5386 \\ DOI 10.15835/buasvmcn-agr: 11731
}

\begin{abstract}
Natura 2000 ROSCI0233 Someșul Rece Site is a protected area of community interest; the site has natural richness and landscapes of great beauty and a big variety of important flora and fauna. An important piece to achieve the aim, consists of the local inhabits of the area. In order to help local communities identifying the benefits of living in or near Natura 2000 area, 14 meetings took place, 2 in each of Somesul Rece Site 7 villages: Valea Ierii, Caps, Cerc, Plopi, Răcătău, Măguri and Muntele Rece. The meetings were submitted to informative materials in the form of power-point presentations, leaflits and various posters, and after this presentation, the audience had the opportunity to ask questions. The 14 meetings were a success, and we can say that most of the inhabits of the area found many benefits compared to 2013, when $54 \%$ of the inhabits asked, sad they know no benefits of a Natura 2000 area.
\end{abstract}

Keywords: local development, protected areas, Natura 2000 Network benefits.

\section{INTRODUCTION}

Natura 2000 ROSCI0233 Someșul Rece Site is a protected area of community interest; the site has natural richness and landscapes of great beauty and a big variety of important flora and fauna. The area has been designated a site of community importance in order to maintain the biological diversity and for conservation of the habitats and species of community interest. They have to realise that living in or near a Natura 2000 Site brings them benefits and advantages that they could not have if living in an ordinary area (Grant Application, 2013).

\section{AIMS AND OBJECTIVES}

Improving communication with target group, in order to achieve performant knowledge transferr, by organizing periodic meetings.

\section{MATERIALS AND METHODS}

In order to help local communities identifying the benefits of living in or near Natura 2000 area, 14 meetings took place, 2 in each of Somesul Rece Site 7 villages: Valea Ierii, Caps, Cerc, Plopi, Răcătău, Măguri and Muntele Rece. The meetings were submitted to informative materials in the form of power-point presentations, leaflits and various posters, and after this presentation, the audience had the opportunity to ask questions. Randomly inhabits were questioned, in Octomber 2013, at the beginning of the awareness meetings, and in June 2015, at the end of all the meetings, about the benefits of a Natura 2000 Site. The research methodology used had a margin of error of $2 \%$. Sociological investigation was conducted on a representative sample of the target area , comprising about 100 randomly selected people 
within the local population (Research Report, 2015) The data contained in the questionnaires were entered into a computer database and were statistically processed and presented in the form of statistical indicators illustrative for the level of awareness.

\section{RESULTS AND DISCUSSION}

Regarding the possible benefits that could derive from following the implementation of the management plan for Natura 2000 Somesul Rece Site, the responses were varied but it has been notice a change of perception. The number of those who choose I do not know decreased considerable from $38 \%$ to $15 \%$ and the number of those those who do not see any relevance in this site it decreased by 10 percents compared with 2013. Overall, total number of respondents who see the advantages of a Nature 2000 Site is $70 \%$ and contrary to expectations, the sum of the respondents who see a disadvantage such a Site grew with $3 \%$.

Regarding the possible benefits on several examples that could derive from following the implementation of the management plan for Natura 2000 Somesul Rece Site, the responses were varied but the most visible change you can see at option I do not know/I do not answer where the rate has fallen sharply from $54 \%$ to $8 \%$ which shows that information campaigns have managed to change people's mentality and show them that they can benefit from these Natura 2000. Overall, among the best seen benefits include the fundraising for agriculture from European Union with $13 \%$, job growth in rural areas, which is selected by $11 \%$ of respondents, environmental protection of nature a with a percentage of $12 \%$ followed by increasing ecological tourism with $9 \%$, creation of leisure activities specific to the region with a share of $11 \%$ - As advantages are the existence of compensatory payments by $8 \%$ and getting certified for local products by $10 \%$ (Fig. 2).

\section{CONCLUSION}

Following the meetings, we could notice that the inhabits knew and identified many benefits of Somesul Rece Site in 2015, such as: local economy development $(8 \%)$, environmental protection $(12 \%)$, ecologic turism development (11\%),

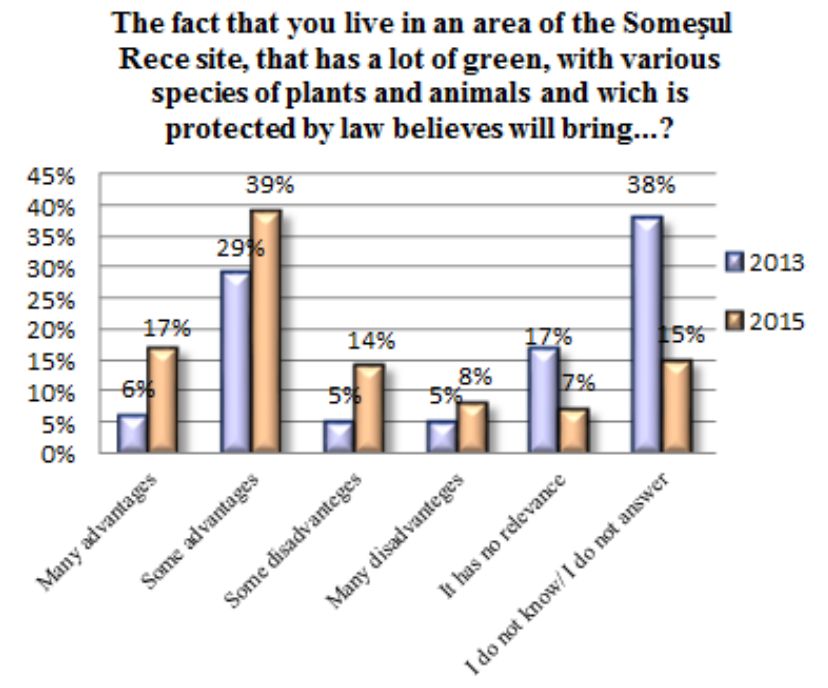

Fig. 1. Possible benefits of the management plan for Natura 2000 Somesul Rece Site

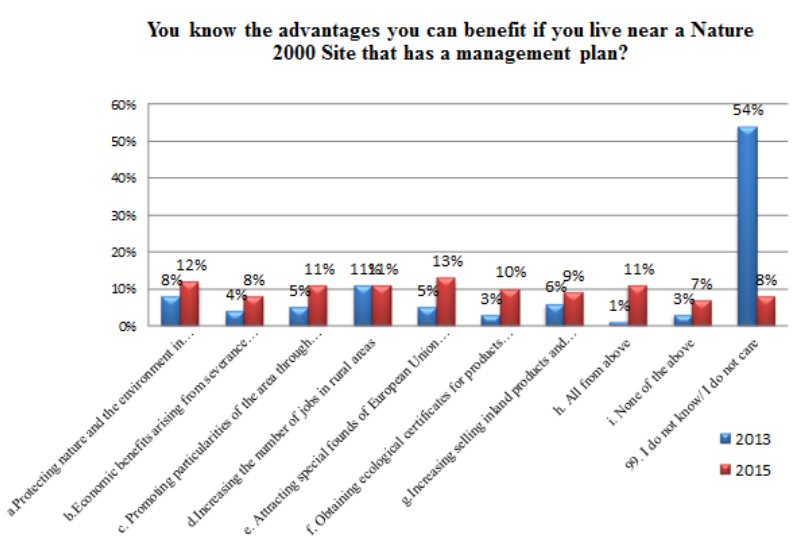

Fig. 2. Example of possible benefits of the management plan for Natura 2000 Somesul Rece Site

promoting local products (9\%) or increasing european funding (13\%). The 14 meetings were a success, and we can say that most of the inhabits of the area found many benefits compared to 2013, when $54 \%$ of the inhabits asked, sad they know no benefits of a Natura 2000 area.

Acknowledgments to Sustenable development of Natura 2000 Somesul Rece Site Project - POS Mediu 2007-2013.

\section{REFERENCES}

1. ***, (2015) Research Report concerning the nevel of awareness of local communities about Somesul Rece Area.

2. ***, (2013). Sustenable development of Natura 2000 Somesul Rece Site - Grant Application 